\title{
Aspects of general antimicrobial properties of skin secretions in the common seal Phoca vitulina
}

\author{
W. Meyer ${ }^{1, *}$, M. Bollhorn ${ }^{1}$, M. Stede ${ }^{2}$ \\ 'Anatomical Institute, School of Veterinary Medicine Hannover, Bischofsholer Damm 15, 30173 Hannover, Germany \\ ${ }^{2}$ Veterinary Investigation Centre for Fish and Fishproducts, 27472 Cuxhaven, Germany
}

\begin{abstract}
Considerable amounts of several saccharide residues ( $\alpha$-D-Man, $\beta$-D-GlcNAc, $\alpha$-D-GalNAc, $\beta$-D-Gal, $\alpha$-DGal, $\alpha$-L-Fuc, NeuNAc) are demonstrated by lectin histochemistry in the sections of the sebaceous glands, and, particularly, the apocrine tubular glands of the common seal. These sugars may be liberated on the skin surface by microbial activities and, then, represent a general antimicrobial protection mechanism of the skin because of their ability to inhibit the adherence of different bacteria and fungi to the epidermis
\end{abstract}

KEY WORDS: Skin secretions - Free sugars - Antimicrobial protection - Seal

The skin surface of most animals is a biotope for numerous micro-organisms. This is also true of marine mammals, where a variety of bacteria and fungi can be found. The composition of this microflora, however, may vary according to internal and external circumstances (Sweeney et al. 1976, Polglase et al. 1986. Ushakova \& Abramova 1989). In pinnipeds, several skin diseases have been recognized that are primarily of infectious etiology. Bacterial conditions included dermatophilosis, streptococcosis, mycobacteriosis, staphylococcosis and others. Fungal conditions were mainly related to dermatophytosis, candidiasis, and Fusarium spp. mycosis (Montali et al. 1981, Dunn et al. 1984, Beckmen et al. 1997). Many of the microbial species involved are opportunistic invaders, i.e. inoffensive commensals that become dangerous when the normal skin biology is disturbed by polluted water, other diseases, skin injuries, decreased immunocompetence, etc. In the common seal, for example, this development is often initiated by severe chemical and mechanical hazards to which the ventral body regions

•E-mail: wmeyer@anat.tiho-hannover.de are frequently exposed, due to sliding and creeping movements on different types of ground (Meyer 1997). Independent of these influences, however, seasonal integumental variations such as the moulting process also seem to be of importance (Montali et al. 1981).

Using lectin histochemistry to demonstrate specific aspects of complex carbohydrates, the present study was designed to provide initial information on possible general integumental mechanisms for controlling microbial activity which are related to the normal structural and functional attributes of the skin, and which respond before specific immunobiological properties of epidermal cells (Bos 1997, Schroeder 1999) are neccessary.

Skin specimens were excised from different body regions (back, abdomen, forefoot, hindfoot) of 4 juvenile and 4 adult freshly dead seals of both sexes. The specimens were fixed in Bouin's fluid, embedded in paraffin, and stained for the determination and differentation of glycoconjugates by applying peroxidase (PO)-labelled lectins (E.Y./Sunbio; Sigma, see also Table 1). This methodical approach used is described in detail elsewhere, including specific control procedures (Meyer et al. 1993, Brooks et al. 1997).

The results obtained are summarized in Table 1 and Figs. 1 to 3 , which illustrate varying distribution patterns of different terminal sugars mainly in the skin glands of all seals studied. The apocrine tubular glands showed a rather distinct reaction staining of the secretory cells and the luminal secretions for most of the lectins, especially in the apical apocrine protrusions, where very strong reactions were visible for Con $A$, BPA, PNA, UEA-I, and LFA. In the sebaceous glands the reaction staining was weaker in all of the structures examined.

The selectivities of the PO-lectins revealed, thus, that the following saccharide residues were clearly 
Table 1 Phoca vitulina. Lectin histochemical reaction intensities in the sebaceous glands and the apocrine tubular glands of the common seal. $0=$ no reaction, $1=$ very weak, $2=$ weak, $3=$ moderate, $4=$ strong 5 = very strong

\begin{tabular}{|c|c|c|c|c|c|c|c|c|c|}
\hline \multirow[t]{2}{*}{ Lectins } & \multicolumn{4}{|c|}{ Sebaceous glands } & \multicolumn{4}{|c|}{ Apocrine glands } & \multirow[t]{2}{*}{ Inhibitory sugar } \\
\hline & $\begin{array}{l}\text { Peri- } \\
\text { pheral } \\
\text { cells }\end{array}$ & $\begin{array}{l}\text { Central } \\
\text { cells }\end{array}$ & Sebum & $\begin{array}{l}\text { Excre- } \\
\text { tory duct } \\
\text { cells }\end{array}$ & $\begin{array}{c}\text { Secre- } \\
\text { tory } \\
\text { cells }\end{array}$ & $\begin{array}{l}\text { Luminal } \\
\text { secre- } \\
\text { tion }\end{array}$ & $\begin{array}{l}\text { Myoepi- } \\
\text { thelial } \\
\text { cells }\end{array}$ & $\begin{array}{l}\text { Excre- } \\
\text { tory duct } \\
\text { cells }\end{array}$ & \\
\hline PO-Con A-DAB & $1-3$ & 1 & 2 & 1 & $2-5$ & $2-4$ & $1-2$ & $3-4$ & $\alpha$-D-Man; $\alpha$-D-GlC \\
\hline PO-WGA-DAB & $1-3$ & $2-3$ & $1-3$ & $1-3$ & $2-4$ & $1-3$ & $1-3$ & $1-3$ & $\beta-D-G l c N A c>N e u$ NAC \\
\hline PO-GSA-II-DAB & $1-3$ & $1-2$ & $1-3$ & $1-2$ & $1-2$ & 1 & $1-2$ & $1-2$ & $\alpha-/ \beta-D-G l c N A C$ \\
\hline PO-DBA-DAB & $1-3$ & $1-3$ & $1-3$ & $1-3$ & $2-3$ & 2 & $1-2$ & $2-3$ & $\alpha$-D-GalNAC \\
\hline PO-SBA-DAB & $1-2$ & $1-2$ & $1-2$ & $1-2$ & $3-4$ & $3-4$ & 1 & $1-2$ & $\alpha-D$-GalNAC $>\alpha-D-$ Gal \\
\hline PO-MPA-DAB & $1-2$ & 1 & $1-2$ & 1 & $1-4$ & $1-3$ & 1 & $1-4$ & $\alpha-D-G a l ; \alpha-D-G a l N A c$ \\
\hline PO-GSA-I-DAB & $1-2$ & $1-2$ & $1-3$ & $1-2$ & $2-4$ & 1 & 1 & $1-2$ & $\alpha-D-G a l_{i} \alpha-D-G a l N A C$ \\
\hline PO-BPA-DAB & $1-3$ & $1-2$ & $1-3$ & $1-2$ & 4 & $1-3$ & $1-2$ & $1-3$ & $\beta$-D-Gal; $\beta$-D-GalNAC \\
\hline PO-PNA-DAB & $1-2$ & $1-2$ & $1-3$ & $1-2$ & $3-5$ & $1-3$ & $1-2$ & $1-4$ & $\beta$-D-Gal; $\beta$-D-GalNAC \\
\hline PO-UEA-I-DAB & $1-3$ & $1-2$ & $1-3$ & $1-2$ & $3-5$ & $1-2$ & $1-2$ & $1-2$ & $\alpha$-L-Fuc \\
\hline PO-LFA-DAB & $1-3$ & $1-2$ & $1-3$ & $1-2$ & $3-5$ & $1-2$ & $1-2$ & $1-3$ & NeuNAC $=$ NeuNGic \\
\hline
\end{tabular}

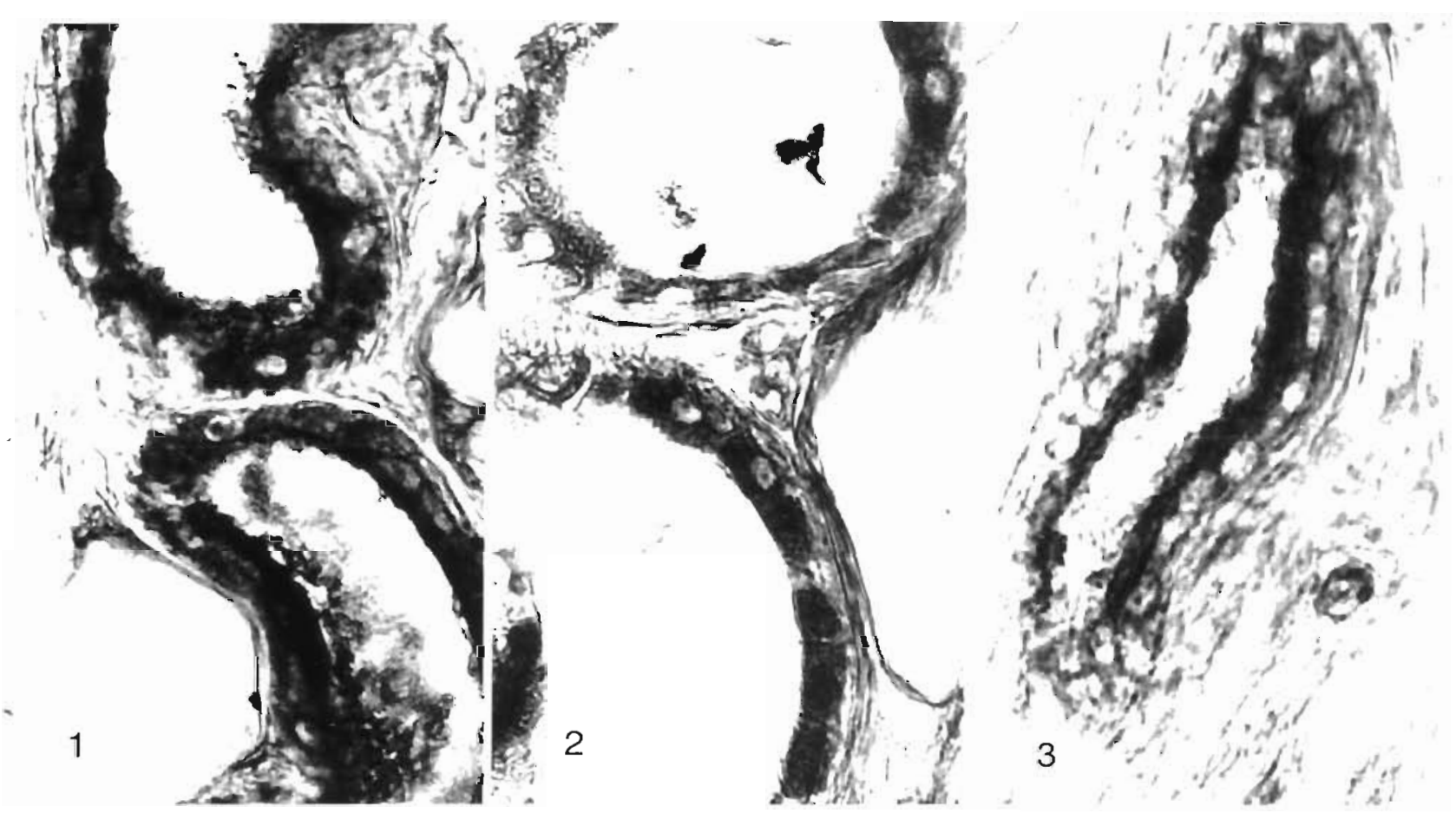

Figs. 1 to 3. Phoca vitulina. Strong lectin histochemical reactions in secretory cells of the apocrine tubular skin glands of the common seal. Fig. 1. BPA ( $\beta$-D-galactose). Fig. 2. UEA-I (L-D-fucose). Fig. 3. LFA. (N-acetylneuraminic acid). All $\times 625$

present, particulary in the secretions of the apocrine tubular skin glands: $\alpha$-o-mannose, $\beta$-D-N-acetylglucosamine, $\alpha-D-N$-acetylgalactosamine, $\beta$-D-galactose, $\alpha$-D-galactose, $\alpha$-1-fucose, and $N$-acetylneuraminic acid. All of these sugars that are liberated on the skin surface from their glycoprotein or glycolipid bases by microbial activities (Noble 1993) have the ability to inhibite the adherence of different bacteria (Sharon et al. 1981, Romero-Steiner et al. 1990, McGavin et al.
1993) and fungi (Critchley \& Douglas 1987, Ollert et al. 1993) to the mammalian epidermis. In this way the concentration of free sugars to a considerable degree may impede the attack of normal skin micro-inhabitants against epidermal integrity, and a general biological protection mechanism becomes obvious. It should be emphasized in this connection that in terrestrial mammals the secretions of the skin glands also contain such terminal sugars, but these sugars are not as con- 
centrated as in the seal (Tsukise \& Meyer 1983, Meyer \& Tsukise 1989, Meyer et al. 1993). The results of this study indicate that further research is warranted, provided that it is possible to obtain fresh skin material from healthy or diseased marine mammals for relevant carbohydrate histochemical processing.

Acknowledgements. We gratefully acknowledge the help given by the Ministry for the Environment and the Chief Veterinary Officer, Reykjavik, Iceland, and the Veterinary Institution Centre for Fish and Fish Products, Cuxhaven, Germany, to obtain the skin material needed. The skin specimens from Iceland were imported with the permission of the Federal Institution for Natural Protection, Bonn, Germany (Bundesamt für Naturschutz, permission no. BE-0326/97).

\section{LITERATURE CITED}

Beckmen KB, Lowenstine LJ, Newman J, Hill J, Hanni K, Gerber J (1997) Clinical and pathological characterization of Northern elephant seal skin disease. J Wildl Dis 33: $438-449$

Bos JD (1997) The skin as an organ of immunity. Clin Exp Immunol 107(Suppl 1):3-5

Brooks SA, Leathem AJC, Schumacher U (1997) Lectin histochemistry. BIOS Scient Publ, Oxford

Critchley IA, Douglas LJ (1987) Role of glycosides as epitheLial cell receptors for Candida albicans. J Gen Microbiol 133:637-643

Dunn JL, Buck JD, Spotte S (1984) Candidiasis in captive pinnipeds. J Am Vet Med Assoc 185:1328-1330

McGavin MH, Krajewska-Pietrasik D, Ryden C, Hook M (1993) Identification of a Staphylococcus aureus extracellular matrix-binding protein with broad specificity. Infect Immunol 61:2479-2485

Meyer W (1997) Immunohistochemical demonstration of transferrin and transferrin receptor in mammalian integu-

Editorial responsibility: Murray Dailey,

Sausalito, California, USA ment. Biotech Histochem 72:223-228

Meyer W, Saglam M, Tanyolaç A, Schwarz R (1993) Carbohydrate histochemistry of skin glands in the Turkish Angora goat. Eur J Morphol 31:157-167

Meyer W, Tsukise A (1989) Histochemistry of complex carbohydrates in the scrotal skin of the monkey Macaca cyclopis (Swinhoe). Z Säugetierkd 54:9-21

Montali RJ, Bush M, Strandberg JD, Janssen DL, Boness DJ, Whitla JC (1981) Cyclic dermatitis associated with Fusarium sp. infection in pinnipeds. J Am Vet Med Assoc 179: $1198-1202$

Noble WC (ed) (1993) The skin microflora and microbial skin disease. Cambridge Univ Press, Cambridge

Ollert MW, Söhnchen R, Korting HC, Ollert U, Bräutigam S, Bräutigam W (1993) Mechanisms of adherence of Candida albicans to cultured human epidermal keratinocytes. Infect Immunol 61:4560-4568

Polglase JL, Alderman DJ, Richards RH, Moss ST (1986) Aspects of the progress of mycotic infections in marine mammals. In: Moss ST (ed) The biology of fungi (4th Int Mar Mycolol Sympj. Cambridge Univ Press, Cambridge, p $155-164$

Romero-Steiner S, Witek T, Balish E (1990) Adherence of skin bacteria to human epithelial cells. J Clin Microbiol 28: $27-31$

Schroeder JM (1999) Epithelial peptide antibiotics. Biochem Pharmacol 57:121-134

Sharon N, Eshdat Y, Silverblatt FJ, Ofek I (1981) Bacterial adherence to cell surface sugars. Ciba Found Symp 80: $119-141$

Sweeney JC, Migaki G, Vainik PM, Conklin RH (1976) Systemic mycoses in marine mammals. J Am Vet Med Assoc 169:946-948

Tsukise A, Meyer W (1983) Histochemistry of complex carbohydrates in the hairy skin of the domestic pig. Histochem J 15:845-860

Ushakova NA, Abramova OYu (1989) Incidence and composition of bacterial flora on the skin of marine mammals as an indicator of their physiological status. Mikrobiologiya 58: $864-870$ (in Russian)

Submitted: December 20, 1999; Accepted: January 27, 2000 Proofs received from author(s): May 5, 2000 